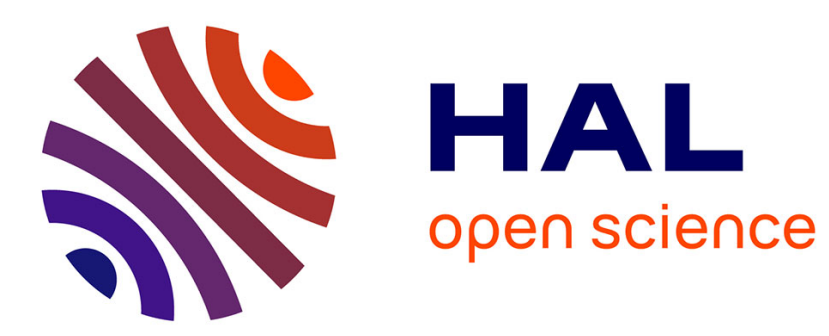

\title{
Formation of the Alpine orogen by amagmatic convergence and assembly of previously rifted lithosphere
}

\author{
Anders Mccarthy, Julie Tugend, Geoffroy Mohn
}

\section{- To cite this version:}

Anders Mccarthy, Julie Tugend, Geoffroy Mohn. Formation of the Alpine orogen by amagmatic convergence and assembly of previously rifted lithosphere. Elements, 2021, 17 (1), pp.29-34. 10.2138/gselements.17.1.29 . hal-03204156

\section{HAL Id: hal-03204156 \\ https://hal.sorbonne-universite.fr/hal-03204156}

Submitted on 21 Apr 2021

HAL is a multi-disciplinary open access archive for the deposit and dissemination of scientific research documents, whether they are published or not. The documents may come from teaching and research institutions in France or abroad, or from public or private research centers.
L'archive ouverte pluridisciplinaire HAL, est destinée au dépôt et à la diffusion de documents scientifiques de niveau recherche, publiés ou non, émanant des établissements d'enseignement et de recherche français ou étrangers, des laboratoires publics ou privés. 


\section{Formation of the Alpine orogen by amagmatic}

2 convergence and assembly of previously rifted lithosphere

3 Anders McCarthy ${ }^{1}$, Julie Tugend ${ }^{2}$ and Geoffroy Mohn ${ }^{3}$

$4{ }^{1}$ School of Earth Sciences, University of Bristol, BS8 1RJ, Bristol, UK and Institute for

5 Marine and Antarctic Studies, University of Tasmania, 7004, Battery Point, Australia

6 2Sorbonne Université, CNRS-INSU, Institut des Sciences de la Terre Paris, ISTeP UMR

7 7193, F-75005 Paris, France (julie.tugend@gmail.com)

$8 \quad{ }^{3}$ CY Cergy Paris Université, GEC, F-95000 Cergy, France

9 ABSTRACT

10 The tectonic and magmatic characteristics of the Alps and Pyrenees during

11 convergence are quite distinct from characteristics associated with classic Benioff-type

12 oceanic subduction. From the initiation of subduction at passive margins until the

13 onset of continental collision, the closure of the Western Tethys never produced a long-

14 lived magmatic arc. This is a consequence of the 3-D architecture of the Western

15 Tethys (a series of hyper-thinned basins and continental blocks) and its narrow width

$16(<500-700 \mathrm{~km})$ prior to convergence. Subduction primarily involved the slow and

17 amagmatic subduction of a narrow domain of dry lithospheric mantle. This type of

18 congested Ampferer subduction led to the sequential and coherent accretion of

19 inherited rifted domains which today form the Alpine and Pyrenean orogens. 
20 KEYWORDS: amagmatic subduction; Ampferer-type, Benioff-type, hyperthinned 21 basins, continental subduction

\section{INTRODUCTION}

24 Benioff-type oceanic subductions are typically characterized by compositionally 25 variable and extensive magmatism from the onset of subduction initiation to mature 26 arc magmatism (Grove et al. 2012; Stern et al. 2012; Jicha and Jagoutz 2015; Li et al. 272019 and references therein). Although variations in magmatism might occur over plateaus, might locally inhibit magmatism, the development of extensive magmatism during subduction is a consequence of two main factors: 1) upper-plate extension and adiabatic decompression mantle melting, particularly during subduction initiation or back-arc spreading; 2) dehydration ( \pm melting) of subducted oceanic lithosphere at depths of $\sim 100 \mathrm{~km}$, which triggers flux-melting of the mantle wedge (Grove et al. 2012 and references therein).

However, evidence of magmatism in the Alps and Pyrenees remains sparse to nonexistent during convergence (e.g., Trümpy 1975; McCarthy et al. 2020 and references therein). We address this conundrum by targeting the Jurassic- Cenozoic magmatic and tectonic history of the Western Tethys from rifting to subduction and collision. We also include the Pyrenean orogen because it shares similarities with the Western and Central Alps in term of its pre-orogenic setting (a series of former 
41 hyper-thinned rift basins) and lack of magmatism during convergence. We show

42 that in order to constrain the mechanisms of lithospheric foundering and recycling,

43 it is crucial to clearly characterize the lithosphere prior to convergence in terms of

44 its architecture, size, and the lithologies of the "subductable" domain.

\section{MAGMATISM IN THE ALPS AND PYRENEES}

46 Paleogene magmatism in the Western and Central Alps (Fig. 1A), typically found as

47 small plutons and dykes within the Alpine Orogen, occurs immediately prior to, and

48 during, continental collision (43-29 Ma) (Müntener et al. 2021 this issue). The

49 volume of this short-lived Paleogene magmatism, normalized to the length of the

50 arc, is several orders of magnitude smaller than the volume of magmatism at mid-

51 ocean ridges and typical arc systems (e.g., Jicha and Jagoutz 2015) (Fig. 1B).

52 However, evidence of magmatism in the Alps occurring prior to $43 \mathrm{Ma}$-from the

53 initiation of subduction (100-90 Ma) to subduction of the Western Tethys -

54 remains unheard of in the Alps (e.g., Trümpy 1975; McCarthy et al. 2018, 2020). In

55 addition, no evidence of subduction-related Paleogene magmatism is found in the

56 Pyrenees. This implies that either no magmatism occurred during a 40-50 My

57 period of subduction or that volcanic edifices and plutons were formed during

58 subduction but were subsequently very efficiently eroded and redeposited in

59 adjacent sedimentary basins.

60 Arc magmas generally contain zircons crystallized during magma differentiation in

61 the crust. Once volcanic and plutonic edifices are eroded, these zircons are

62 deposited in nearby sedimentary basins. Therefore, dating populations of detrital 
63 zircons can provide accurate snapshots of magmatism through time. Detrital zircon

64 populations from continental arcs reveal the near-continuous output of volcanism

65 over hundreds of millions of years, with detrital zircon populations overall

66 mirroring the population of magmatic zircons (Paterson and Ducea 2015). Similar

67 patterns are identified along intra-oceanic arcs, albeit over shorter timescales. For

68 example, in the western Pacific, detrital zircon populations from 25-40 Ma

69 volcaniclastic sediments shed from the juvenile Izu-Bonin Arc show a similar

70 evolution in zircon crystallization ages with time of deposition, as evidenced by

71 biostratigraphy and magnetostratigraphy (e.g., Barth et al. 2017). These overlapping

72 ages imply that volcaniclastic rocks were rapidly erupted and deposited in proximal

73 basins.

74 Detrital zircons in sediments deposited during convergence in the Western Tethys 75 should, therefore, record a "lost" Alpine magmatic arc, if, in fact, it existed. A 76 compilation of $\mathrm{U}-\mathrm{Pb}$ detrital zircon ages from sediments deposited in the last 300

77 My for both the Alps and the Pyrenees (data compiled in McCarthy et al. 2018, 2020)

78 shows a clear gap in zircon ages, which persists from rifting until the onset of

79 continental collision (Fig. 1C). This dearth of magmatic zircons in the Western and

80 Central Alps covers the timeline from the onset of subduction initiation between 90

81 Ma and 100 Ma until shortly prior to the onset of continental collision (e.g., Handy et

82 al. 2010; Zanchetta et al. 2012; McCarthy et al. 2018), during which only minor

83 volumes of arc-like magmatism were produced (Fig. 1A). 
84 This magmatic zircon gap notably coincides with subduction- related eclogite-facies high-pressure metamorphism of continental fragments from the Adria margin, which reached the peak metamorphic conditions of $1.5-2.0 \mathrm{GPa}$ at $65-75 \mathrm{Ma}$, implying a subducted depth of $\sim 50-70$ km (e.g., Berger and Bousquet 2008; Agard and Handy 2021 this issue). This zircon gap also coincides with the initial slow subduction of hydrated oceanic domains, for which metamorphic garnet documents a prograde metamorphism at 1.1-1.4 kbar, likely starting as early as 70-80 Ma, before reaching peak eclogite-facies metamorphism at 2-3 GPa, $38-40$ Ma (Skora et al. 2009 and references therein). The lack of magmatic zircons derived from arc magmas during these events implies that there is a $40-50$ million year window when typical conditions relevant to hydrous arc magmatism-namely, a hydrated oceanic slab subducted to $50-150 \mathrm{~km}$ depth, which should lead to flux-melting of the mantle wedge (Grove et al. 2012)—did not produce any magmatism. Instead, detrital zircons reveal a "magmatic arc gap" consistent with the observed lack of plutonic and volcanic rocks (Fig. 1A) (Trümpy 1975; McCarthy et al. 2018). Notably, the detrital zircon record in the Pyrenees also shows no detrital zircon population from rifting to continental collision (Fig. 1C). 

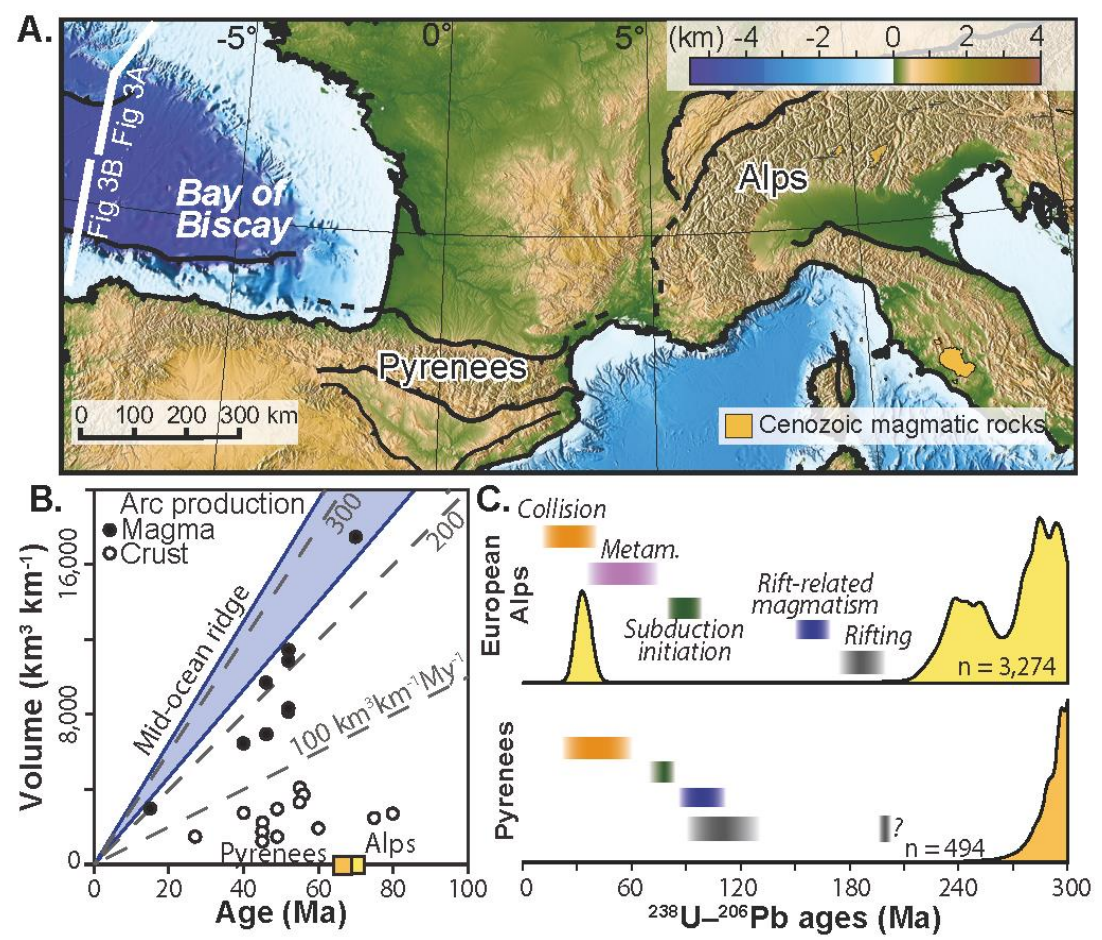

102 Figure 1: Fingerprinting magmatism during convergence along the Western Tethys.

103 (A) The distribution of Cenozoic magmatism (orange) in the Alps, Pyrenees and 104 Apennines. Note the locations of two seismic profile lines (white lines) in the Bay of 105 Biscay: these are given as cross-sections in Figures 3A and 3B. (B) Estimated volume 106 of magma production and crust production in arc systems and mid-ocean ridges 107 (From Jicha and Jagoutz 2015) as compared to such production in the Alps and 108 Pyrenees (From McCarthy et al. 2020). Volume of magmatism is normalized per 109 kilometre of arc length (km3/km). (C) Distribution of detrital zircon ages from 300 110 Ma to present, showing important geodynamic markers (bars represent different 111 geological processes) related to the opening and closing of the Western Tethys. 112 Abbreviation: Metam = high-pressure metamorphism during subduction.

\section{THE ARCHITECTURE OF THE WESTERN TETHYS}

114 The history of the Western Tethys is related to the geodynamic evolution of Western

115 Europe upon the opening of the Central and North Atlantic systems (Fig. 2A). The

116 Western Tethys was hemmed in between two wide oceanic domains, namely the 
117 Atlantic Ocean to the west and the Neotethys Ocean to the east, and consisted of a 118 series of rift basins floored by hyperthinned crust, exhumed subcontinental mantle, 119 and embryonic oceans formed in Jurassic-Cretaceous times between Europe and 120 Adria (Alps) and Europe and Iberia (Pyrenees). Remnants of the Western Tethys are 121 found in the Western and Central Alps, Apennines, and Pyrenees and form atypical 122 ophiolitic sequences dominated by mantle rocks, sparsely distributed pillow lavas, 123 lava flows, and gabbroic bodies (see Rampone and Sanfilippo 2021 this issue) partly 124 overlain by their syn- to post-rift sedimentary cover. Sparse basaltic and gabbroic 125 bodies of mid-ocean ridge basalt (MORB) affinity found preserved in the Alps and 126 Apennines reveal a short-lived phase of magmatism, with magmatic zircon ages 127 typically between $155 \mathrm{Ma}$ and $165 \mathrm{Ma}$ (Manatschal and Müntener 2009). These 128 ophiolites are characterized by almost amagmatic spreading accommodated by 129 kilometre-scale concave-downwards detachment faults that exhumed mantle rocks 130 and gabbros to the sea floor, comparable to magma-poor and (ultra)slow-spreading 131 systems such as the Mid-Atlantic Ridge and the Southwest Indian Ridge (e.g., 132 Lagabrielle et al. 2015 and references therein). Published chemical analyses of 133 MORB-like basalts that originally formed in the Western Tethys have $\mathrm{Ti}$ and $\mathrm{V}$ 134 abundances similar to MORB from (ultra)slow mid-ocean ridges, implying that these 135 basalts shared similar sources and partial melting processes and are unlike 136 magmatism associated with subduction initiation (Fig. 2B).

137 Certain remnants of the Western Tethys that are found in Alpine ophiolites also 138 preserve pre- and syn-rift contacts between thinned continental crust and 139 subcontinental mantle; syn-rift sedimentary deposits also directly overly exhumed 
140 mantle, and there are large continental blocks (allochthons, or microcontinents)

141 separated by heterogeneous mantle domains. The characteristics of these remnants 142 are analogous to present-day ocean-continent transitions as seen in Iberian and 143 Newfoundland (Canada) margins (e.g., Manatschal and Müntener 2009 and 144 references therein) (Fig. 2C).

Along the narrowest sections of the Pyrenean basins, the Western Tethys did 146 not exceed a width of $\sim 150 \mathrm{~km}$, with exhumed subcontinental mantle typically less 147 than $50 \mathrm{~km}$ wide (e.g., Tugend et al. 2015). Palaeogeographic reconstructions 148 suggest that the Western Tethys reached a maximum width of 500-700 km along 149 the Western and Central Alps prior to convergence (Rosenbaum and Lister 2005). 150 Overall, the Western Tethys represents a large-scale pinch-and-swell architecture 151 where continental blocks of variable size (from kilometre-scale allochthons to 152 microcontinents tens of kilometres wide) were separated by hyper-thinned rift 153 basins and exhumed mantle domains (Figs. 2A, 2C) (Manatschal and Müntener 154 2009; Mohn et al. 2010; Manzotti et al. 2014; Tugend et al. 2015 and references 155 therein). A large part of the Jurassic and Cretaceous extension of the Western Tethys 156 was, therefore, accommodated by the extreme thinning of the continental 157 lithosphere. Measurements compiled from present-day rifted margins suggest that 158 the width of hyper-thinned crustal domains may range from $\sim 20 \mathrm{~km}$ to $\sim 80 \mathrm{~km}$ 159 (Chenin et al. 2017) prior to the exhumation of variably wide domains of exhumed 160 subcontinental mantle. The extent to which the 500-700 km wide Western Tethys 161 was underlain by an oceanic lithosphere that had formed at an active spreading 162 centre is, therefore, unclear. However, based on the Jurassic timing of short-lived 
MORB magmatism in the Western Tethys and ultraslow spreading rates $(<2 \mathrm{~cm} / \mathrm{y})$, Manzotti et al. (2014) estimated a width of the Piemonte-Liguria Ocean (or Basin) of 200-300 km (Fig. 2A). In spite of the large uncertainties, these estimations, combined with the estimated width of rifted domains, are consistent with a maximum extension of 500-700 km for the Western Tethys in what would become the Western Alps, as suggested by Rosenbaum and Lister (2005).
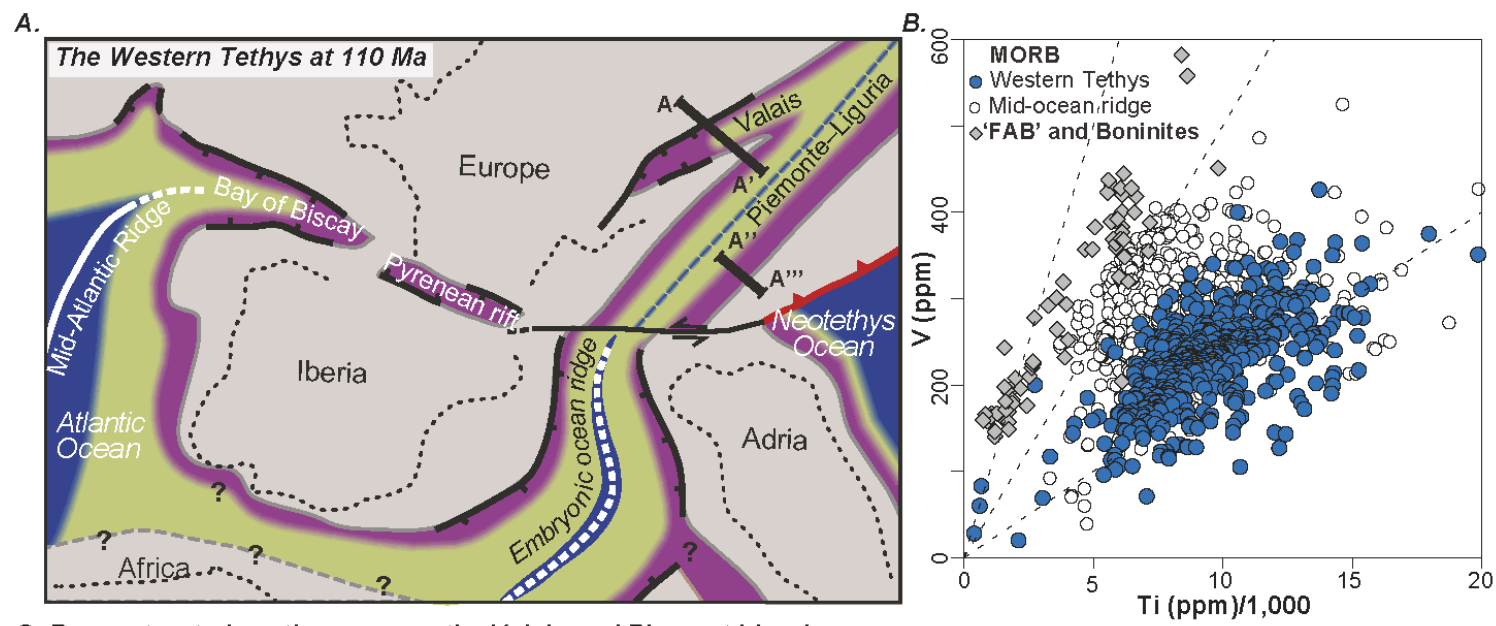

C. Reconstructed sections across the Valais and Piemont Liguria

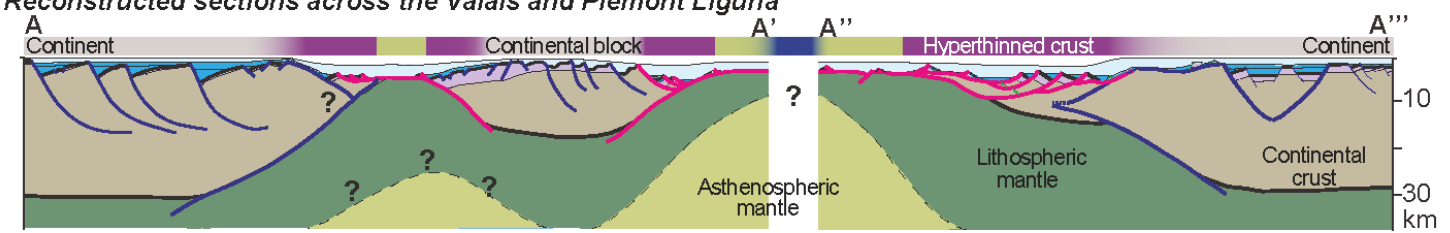

Figure 2: (A) Palaeogeographic reconstruction of the Western Tethys at $110 \mathrm{Ma}$. Note locations of the two sections A-A' and A"-A"'. After Mohn et al. (2010) and Tugend et al. (2015). (B) Compilation of Ti and V compositions from published midocean ridge basalt (MORB)-like ophiolitic rocks originally formed in the Western Tethys (filled circles); from published data for MORBs from (ultra-) slow-spreading mid-ocean ridges (the Atlantic Ridge and the Gakkel Ridge) (open circles); and depleted tholeiitic basalt and forearc basalt ('FAB') and boninites from the IzuBonin Mariana Arc (data from Li et al. 2019 and references therein). (C) Transect through the wider domains of the Western Tethys (Piemonte-Liguria Basin and 
179 Valais Basin) illustrating how rift-related extension was accommodated by 180 (hyper)extension of continental lithosphere. For location of sections see Figure 2A. 181 From Mohn et al. (2010).

\section{ACCOMMODATING CONVERGENCE AT HYPERTHINNED BASINS}

The initial stages of convergence along a rift basin and passive margin are well documented along the Bay of Biscay-Pyrenean system (Tugend et al. 2014). Seismic imaging along the Northern Bay of Biscay reveals that deformation has been accommodated along a series of thrust slices located at the edge of the continental crust where mantle is exhumed (Tugend et al. 2014) (Fig. 3A). Increasing amounts of convergence accommodated along the Northern Iberia margin (southern Bay of Biscay) led to the almost complete overprint of the former hyper-thinned margin and its incorporation as part of the accretionary prism (Gallastegui et al. 2002; Tugend et al. 2014, 2015) (Fig. 3B). These seismic observations and interpretations highlight how compressional deformation was initiated upon convergence and highlights how the Bay of Biscay represents a unique place where the initial stages of subduction at passive margins are preserved. The transitions between rifted margin domains and, notably, between hyper-thinned continental crust and exhumed mantle represent key weaknesses which can accommodate deformation at the onset of convergence (Tugend et al. 2014). This convergence may evolve to become a forced subduction initiation along a passive margin, as suggested by numerical modeling (McCarthy et al. 2020). 


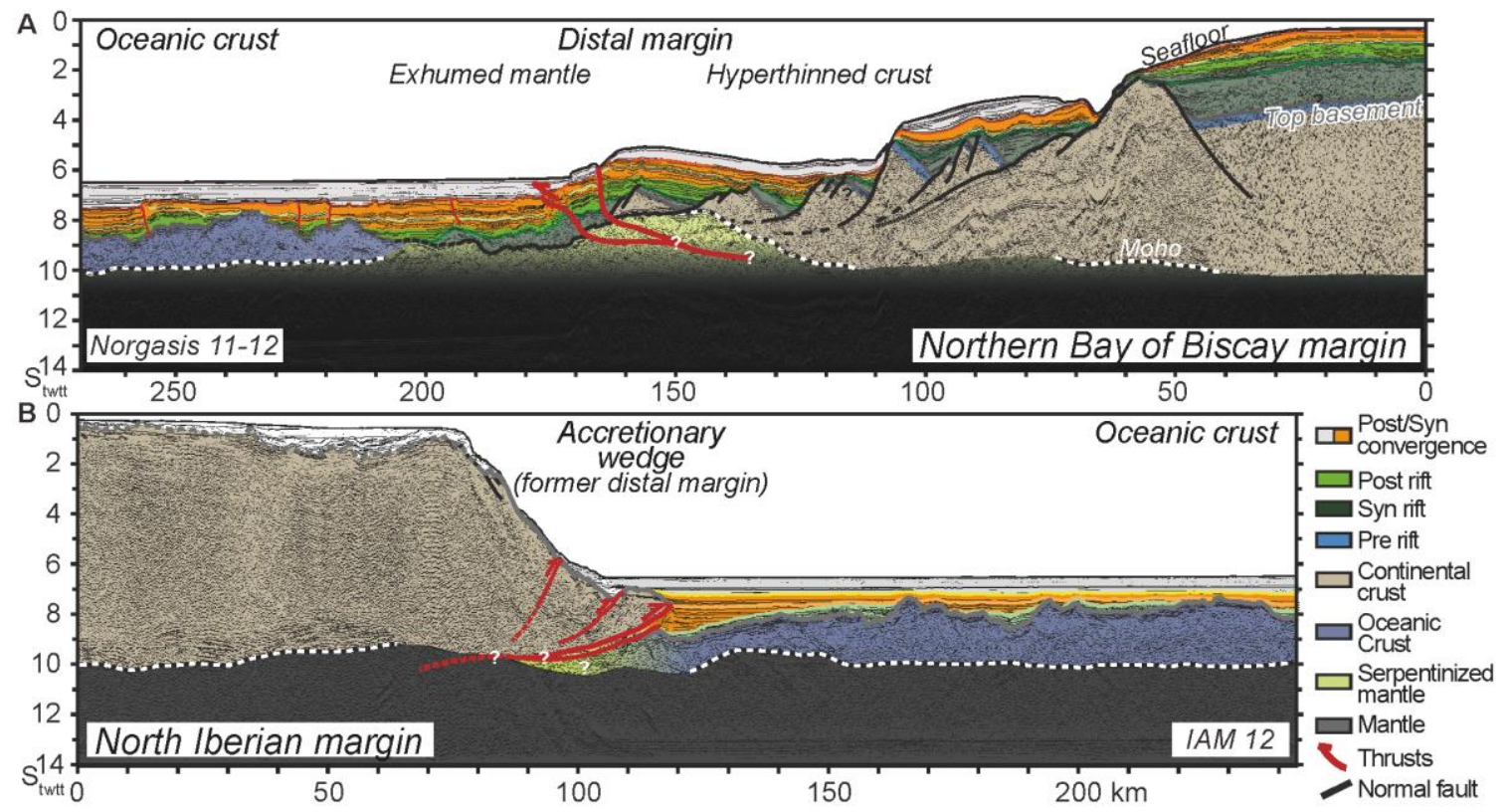

Figure 3: (A) Interpretation of seismic imaging of hyperthinned passive margin 204 along the northern margin of the Bay of Biscay, illustrating how deformation is accommodated along the ocean-continent transition during convergence. From Tugend et al. (2014). (B) Interpretation of seismic imaging of accretionary wedge along the opposite north Iberian margin, on the southern side of the Bay of Biscay. Location of the seismic transects can be found in Figure 1. Abbreviation: Stwtt = 209 two-way-travel-time in seconds.

211 Field mapping and petrological studies along the Central Alps have revealed

212 complex lithostratigraphic associations, including continental crust, serpentinized 213 mantle, and pre to post-rift sediments related to Jurassic rifting (Fig. 4). Such 214 associations and related tectonic structures are the result of the coherent 215 underthrusting (as large thrust sheets) of large fragments of the former ocean- 
216 continent transition below the continental margin during convergence (Mohn et al.

217 2010, 2011). Tectonometamorphic studies reveal an abrupt change in metamorphic

218 conditions and deformation style within the former ocean-continent transition zone

219 of the Adriatic margin (Mohn et al. 2011; Picazo et al. 2019 and references therein).

220 Segments that represent the Adriatic upper plate (Bernina-Err-Platta, a low

221 greenschist facies unit) have not been extensively affected by Alpine metamorphic

222 overprint during subduction and collision. In contrast, accreted lower plate

223 sequences (Malenco-Margna Sella, an epidote-amphibolite facies unit that reached

$224 \sim 0.5-0.7 \mathrm{GPa}$ and $450-500{ }^{\circ} \mathrm{C}$ ) show higher $\mathrm{P}-\mathrm{T}$ conditions and pervasive Alpine

225 deformation consistent with being underthrust during convergence. This change in

226 degree of metamorphism occurs within exhumed mantle domains between the

227 hyper-thinned continental margin of Adria and the continental allochthons further

228 oceanward (Figs. 4B, 4C) (Mohn et al. 2010 and references therein). In accordance

229 with observations from the Bay of Biscay margins, field and petrological evidence in

230 the Central Alps indicates that subduction initiation occurred at the edge of hyper-

231 thinned continental crust. Following subduction initiation, rift-related features, such

232 as extensional shear zones and continental allochthons, may typically control the

233 localization of large-scale shear zones that accommodated compression during

234 subduction (e.g., Mohn et al. 2011) (Figs. 4B, 4C). Therefore, the plate interface

235 between the subducting plate and the upper plate is formed of a wide domain of

236 sequentially underthrusted coherent lithospheric slices from the downgoing plate

237 (Fig. 4). Similarly Beltrando et al. (2014) and Lagabrielle et al. (2015) showed that

238 rift-related lithostratigraphic associations (e.g., syn- to post-rift sediments 
240 gabbroic bodies) can still be identified even in the high-pressure (blueschist-

241 eclogite facies) domains of the Western Alps. Despite having a pervasive Alpine

242 metamorphic overprint, rocks of the ocean-continent transitions and the slivers of

243 ultra-slow-spreading oceanic lithosphere can still be coherently preserved and

244 identified throughout the Alpine orogen (Beltrando et al. 2014; Lagabrielle et al.

245 2015).

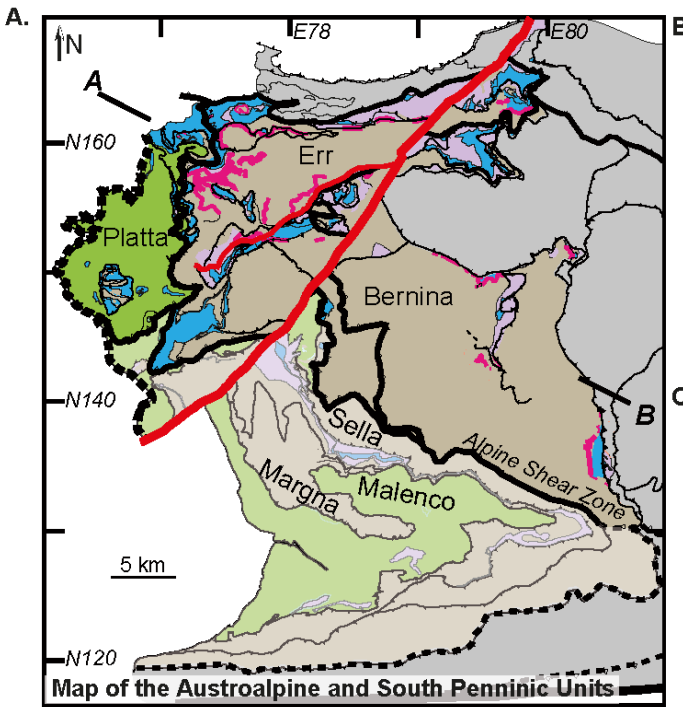

B. Present-day Alpine cross-section

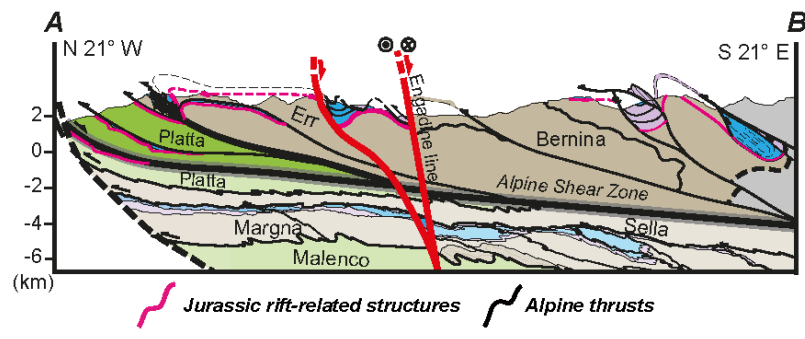

C. Palinspastic reconstruction of the Adriatic margin

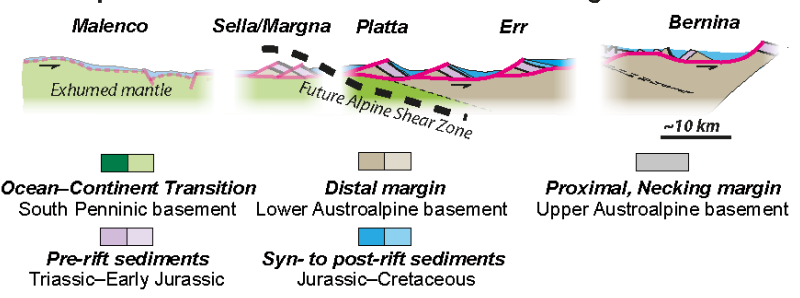

248 Figure 4 (A) Simplified tectonic map along the Central Alps (Eastern Switzerland)

249 highlighting continental units from the Adria margin (Austroalpine: Err, Bernina,

250 Margna-Sella) and exhumed mantle and oceanic units (Penninic: Platta and

251 Malenco). Note location of section line A-B. From Mohn et al. (2011). (B) Present-

252 day Alpine crosssection, taken along line A-B in Figure 4A. The thick black line is a

253 major Alpine Shear Zone that delimits units from the distal Adriatic margin with

254 distinct Alpine overprint. Above the shear-zone, the Upper Platta, Err and Bernina

255 are poorly affected by Alpine deformation. Below the shear-zone, the underthrusted 
256 Lower Platta, Malenco, Margna-Sella Units are affected by pressure-dominated 257 (subduction-related) Alpine metamorphism. Thick, near-vertical, lines (Engadine 258 line) are Cenozoic strike-slip faults crosscutting the Alpine nappe stack. (C) 259 Palinspastic reconstruction of the Adria margin showing the location of subduction 260 initiation within the Continent-Ocean Transition of the Adriatic margin (Future 261 Alpine Shear Zone). The darker, more pronounced, colours represent the upper 262 plate (with a weak Alpine metamorphic overprint); the lighter colours (strong 263 Alpine overprint) represent the lower-plate accreted sequences.

266 Tectonic, metamorphic, and sedimentary fingerprints related to subduction 267 initiation are preserved in the Western Tethys (Fig. 5). Plate kinematic 268 reconstructions indicate that Africa and Adria followed a NE trajectory starting from $269 \sim 85-100$ Ma recorded by slow rates of convergence $(\sim 1-2 \mathrm{~cm} / \mathrm{y})$ in the Western 270 Tethys (Rosenbaum and Lister 2005). Convergence is accommodated by highly 271 oblique to strike-slip motions along the former Adriatic margin and upper-plate 272 compression at $\sim 85-100 \mathrm{Ma}$, leading to the forced subduction of the Western 273 Tethys under Adria (e.g., Rosenbaum and Lister 2005; Zanchetta et al. 2012). Along 274 the upper plate, compression is recorded by the dating of thrust faults, as well as by 275 syn-sedimentary deformation of detrital turbidites (the Lombardian Basin of the 276 Southern Alps) (Zanchetta et al. 2012 and references therein). In addition, the oldest 277 deep-water conglomerates and sandstones (Alpine Flysch), which resulted from the 278 erosion of a nascent wedge along the Western and Central Alps, are $\sim 90-100 \mathrm{Ma}$ 279 (e.g., Handy et al. 2010; Agard and Handy 2021 this issue). In terms of subduction- 
280 related metamorphism, continental fragments from the Adriatic passive margin were affected by peak eclogite-facies metamorphism at 75-65 Ma along the Western Alps (e.g., Agard and Handy 2021 this issue). The peak metamorphism of continental fragments occurs prior to prograde and peak metamorphism of the oceanic domains (Fig. 5) (e.g., Berger and Bousquet 2008 and references therein). From all these observations, the closure of the Western Tethys along the Western and Central Alps, 286 from $\sim 90-100 \mathrm{Ma}$ until continental collision in the Western Alps at $\sim 34-32 \mathrm{Ma}$, most likely occurred as a consequence of highly oblique, slow, and forced 288 subduction that had initiated at a hyper-thinned passive margin.

The record of subduction initiation at the Western Tethys passive margins is unlike the magmatic response to intraoceanic subduction initiation. Although subduction initiation mechanisms are likely diverse and complex, one general model has been

292 developed on the basis of two examples. First, Neotethys supra-subduction-zone 293 ophiolites formed upon subduction initiation (e.g., Stern et al. 2012 and references 294 therein). Second, the development of the Izu-Bonin-Mariana Arc, where intra295 oceanic subduction initiated at 50-52 Ma and formed a long-lived intraoceanic arc 296 (Stern et al. 2012; Li et al. 2019 and references therein). (Fig. 5). These systems are 297 characterized by extensive upper-plate extension and variably extensive hydrous 298 shallow mantle \pm slab melting (e.g., depleted tholeiitic basalts or "forearc basalts", 299 boninites, and high-Mg andesites) upon subduction initiation. Subduction initiation 300 is then followed shortly after either by obduction, as was the case for the Neotethys 301 ophiolites (Stern et al. 2012 and references therein), or, in the case of the Izu302 Bonin- Mariana Arc, the development into a mature arc volcanic system within $\sim 7$ 
303 My after subduction initiation (Fig. 5). Thus, a variety of compositionally distinct 304 magmas can be produced and erupted within a distinctively short timeframe upon 305 intra-oceanic subduction initiation.

\section{A. Hyperthinned basins}

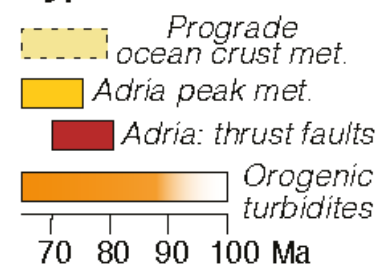

B. Intra-oceanic

Tisiand arc

$\square$ High-Mg andesites

$\square$ Boninites

306

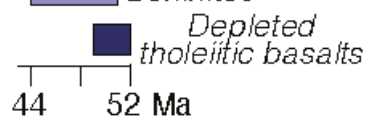

307 Figure 5: Two contrasting tectonic responses to subduction initiation. (A) An 308 amagmatic response to subduction initiation at hyper-thinned basins and passive 309 margins as recorded in the Western and Central Alps. The dotted line part of the 310 "prograde metamorphism of ocean crust" bar signifies uncertainty as to when 311 garnet started growing during prograde metamorphism (Skora et al. 2009). 312 Timescales are from Skora et al. (2009), Zanchetta et al. (2012 and references 313 therein) and Handy et al. (2010 and references therein). (B) The short-term 314 magmatic response to intraoceanic subduction initiation of the Izu-Bonin-Mariana 315 Arc. After Stern et al. (2012 and references therein). Abbreviation: met = 316 metamorphism. 


\section{SHUTTING DOWN MAGMATISM}

319 The (ultra-)slow-spreading Western Tethys was dominated by serpentinized mantle 320 and hydrated oceanic sediments, representing the main reservoirs of volatiles that 321 should typically drive arc magmatism. So, why was magmatism so sparse, played 322 such a late role during convergence in the Alps, and was nonexistent in the Pyrenees 323 following subduction initiation?

324 Initially, unlike intra-oceanic subduction initiation, upper plate compression during 325 the onset of convergence (e.g., Zanchetta et al. 2012) likely inhibited decompression 326 driven magmatism. Then, because even a small percentage (10\%-15\%) of 327 serpentinization lowers the brittle strength of peridotites (Escartín et al. 2001), the 328 hydrated upper layers of the Western Tethys, namely the serpentinites and oceanic 329 sediments, are likely to have been efficiently sheared off from the underlying dry 330 peridotites during forced convergence and then sequentially accreted as coherent 331 slivers to the nascent orogenic wedge (Fig. 4B) (e.g., Mohn et al. 2010; Beltrando et 332 al. 2014). Numerical modeling supports this scenario (McCarthy et al. 2020). The 333 subducting slab will, therefore, primarily be dry lithospheric mantle (Fig. 6) 334 (McCarthy et al. 2018, 2020). The combination of a highly oblique and slow subduction and decoupling of hydrated lithologies from a downgoing dry slab would then form a congested subduction zone characterized by the inefficient subduction of hydrated lithologies. This would have suppressed magmatism for up to 40-50 My even as subducted continental and oceanic fragments were affected by prograde and peak high-pressure metamorphism starting at 70-80 Ma (Fig. 5). Further west along 
340 the Pyrenean basins (Tugend et al. 2014), the combination of narrow $(<150 \mathrm{~km}$ )

341 hyper-thinned rift basins, including only limited exhumed mantle domains $(<50$

$342 \mathrm{~km}$ ), implies that the cumulative convergence was likely not sufficient to produce

343 any high-pressure metamorphism nor arc magmatism even upon collision (Fig. 6).
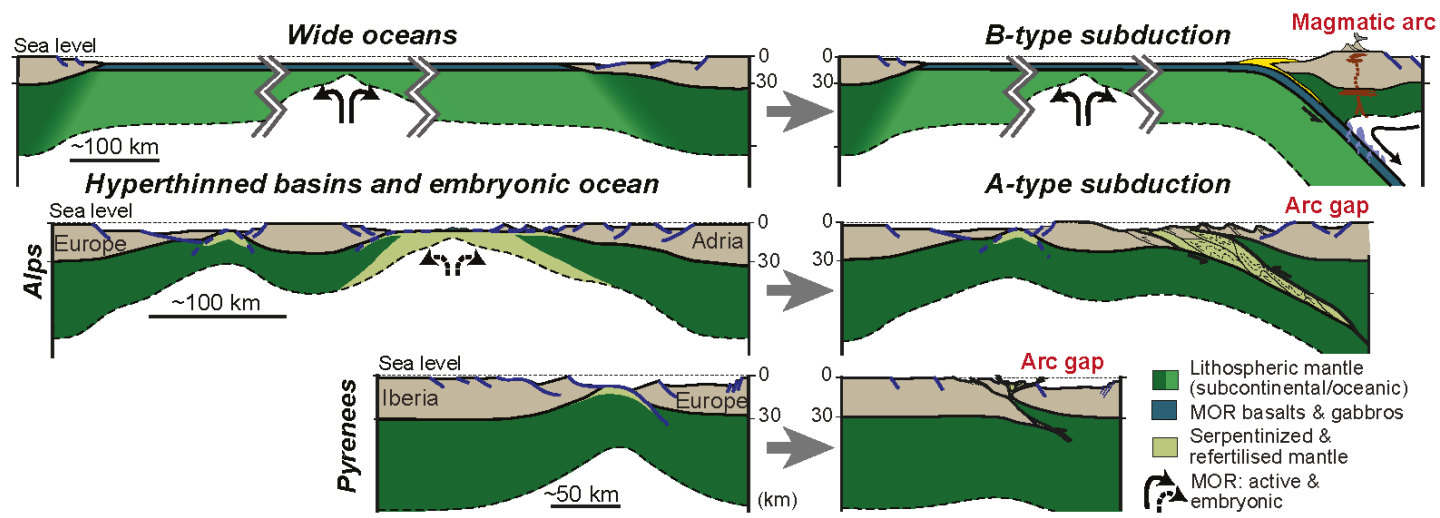

Figure 6: Illustration of Benioff-type ("B-type", with a magmatic arc) oceanic subduction versus amagmatic Ampferer-type ("A-type", without a magmatic arc) continental subduction. Modern subductions represent a continuum between both end-members and are controlled by the pre-existing lithosphere and width of the "subductable domain" prior to the initiation of subduction. MOR = mid-ocean ridge. Modified from McCarthy et al. (2020).

354 In 1911, Otto Ampferer introduced the conceptual idea of downthrusting of continental crust to great depth, or Verschluckung (Ampferer and Hammer 1911), a

356 term later defined as Ampferer-type continental subduction. Almost 65 years later, 
357 as plate tectonics became an accepted and established paradigm, Trümpy (1975) 358 raised the problematic issue of the lack of magmatism in the Alps.

359 Still, the presence of (1) ophiolites interpreted as oceanic lithosphere; (2) (sparse) 360 arc-like magmatism; (3) seismic tomography images of a subducted slab attached to 361 the Alpine Orogen (e.g., Handy et al. 2010 and references therein), and (4) the 362 presence of eclogite-facies continental and oceanic crust (Berger and Bousquet 363 2008) have all been used as strong evidence in favour of a classical Benioff-type 364 oceanic subduction zone in the Alps. Such a plate tectonic model implies the long365 lived efficient subduction of hydrated oceanic crust and sediments. The observed 366 short timescale of Jurassic MORB magmatism recorded in the Alps is then 367 interpreted as a consequence of the efficient subduction of oceanic lithosphere, 368 explaining its poor preservation in the Alpine orogen (Fig. 6). If this were so, 369 processes akin to present-day Benioff-type subduction zones would have driven 370 convergence along the Western Tethys, from subduction initiation to the burial and 371 exhumation of high-pressure rocks and continuing until collision. In this case, the 372 formation of the Alps would have been essentially controlled by buoyancy-driven 373 slab pull and slab roll-back forces, as well as by possible slab breakoff mechanisms.

374 However, we emphasize an alternative view. The Western Tethys was formed 375 subsequent to extreme continental lithosphere extension and the ultraslow plate 376 separation was controlled by regional plate kinematics. As a result, prior to 377 convergence, the Western Tethys can be described as a series of rift basins, floored 378 by hyper-thinned continental crust and exhumed subcontinental mantle as well as 
379 having sporadic embryonic oceanic crust formed by ultraslow spreading (Fig. 2) 380 (e.g., Manatschal and Müntener 2009; Lagabrielle et al. 2015; Tugend et al. 2015). In 381 this scenario, the observed short timescale of Western Tethys MORB magmatism 382 was not a consequence of the efficient subduction of oceanic lithosphere. On the 383 contrary, it would represent the preservation of the rather small $(200-300 \mathrm{~km}$ wide) (Manzotti et al. 2014) and short-lived ultra-slow-spreading events of the 385 Piemonte-Liguria Basin (Fig. 2) (Manatschal and Müntener 2009; McCarthy et al. 386 2020). This view is compatible with the limited width of the Western Tethys 387 inferred from plate kinematic restorations (e.g., Rosenbaum and Lister 2005). Slow 388 convergence forced by regional plate kinematics outside of the Western Tethyan 389 realm was first accommodated at the exhumed mantle domain at the edge of hyper390 thinned continental crust (Fig. 3). Increasing convergence resulted in partial 391 underthrusting and subduction of the distal margin (Fig. 4) prior to that of the 392 embryonic oceanic lithosphere, as supported by the ages of subduction-related 393 metamorphism.

In the above scenario, an Ampferer-type continental subduction would imply that Western Tethyan oceanic lithosphere played a limited and rather passive role

397 during convergence. This mechanism of continental-and congested-Ampferer398 type subduction might lead to alternative interpretations regarding the origins of 399 sporadic, late-stage Paleogene magmatism in the Alps, including the necessity of 
400 slab break-off mechanisms (e.g., Müntener et al. 2021 this issue) and the origin and 401 significance of (ultra) high-pressure metamorphism in collisional orogens..

\section{ACKNOWLEDGMENTS}

\section{REFERENCES}

1. Agard, P., and Handy, M., Ocean subduction dynamics in the Alps, Elements, $17: 9-16$

2. Ampferer O, Hammer H (1911) Geologisches Querschnitt durch dis Ostalper vom Allgau zum Gardasee, Jahrbuch d.k.k. geol. Reichsanstalt. Austria 61:637-710

3. Barth, A P, Tani K, Meffre S., Wooden J L, Coble M A, Arculus R J, Ishizuka O, Shukle J T, (2017). Generation of silicic melts in the early Izu-Bonin arc recorded by detrital zircons in proximal arc volcaniclastic rocks from the Philippine Sea, Geochemistry, Geophysics, Geosystems, 18. 
4. Beltrando, M., Manatschal, G., Mohn, G., Dal Piaz, G.V., Brovarone, A.V., Masini, E., (2014) Recognizing remnants of magma-poor rifted margins in highpressure orogenic belts: The Alpine case study, Earth-Science Reviews, 131, 88-115

5. Berger A, Bousquet R, (2008) Subduction-related metamorphism in the Alps: review of isotopic ages based on petrology and their geodynamic consequences. In Siegesmund S, Fügenschuh B, Froitzheim N, Tectonic aspects of the Alpine-Dinaride-Carpathian System. Geological Society, London, Special Publications 298:117-144.

6. Chenin P, Manatschal G, Picazo S, Müntener O, Karner G, Jackson C, Ulrich M, (2017) Influence of the architecture of magma-poor hyperextended rifted margins on orogens produced by the closure of narrow versus wide oceans, Geosphere, 13(2):559-576.

7. Escartin J, Hirth G, Evans B, (2001) Strength of slightly serpentinized peridotites: Implications for the tectonics of oceanic lithosphere: Geology, 29(11):1023-1026

8. Gallastegui, J., Pulgar, J. A., \& Gallart, J. (2002). Initiation of an active margin at the North Iberian continent-ocean transition. Tectonics, 21(4), 15-1.

9. Grove T, Till C B, Krawczynski M J, (2012) The role of $\mathrm{H}_{2} \mathrm{O}$ in subduction zone magmatism, Annual Review in Earth and Planetary Sciences 40:413-439

10. Handy M R, Schmid S M, Bousquet R, Kissling E, Bernoulli D (2010) Reconciling plate-tectonic reconstructions of Alpine Tethys with the 
geological-geophysical record of spreading and subduction in the Alps. EarthScience Reviews 102:121-158

11. Jicha B R, Jagoutz, O (2015) Magma production rates for intraoceanic arcs. Elements, 11:105-112

12. Lagabrielle Y, Vitale Brovarone A, Ildefonse B (2015) Fossil oceanic core complexes recognized in the blueschist metaophiolites of Western Alps and Corsica. Earth-Science Reviews 141:1-26

13. Li H-Y, Taylor R N, Prytulak J, Kirchenbaur M, Shervais J W, Ryan J G, Godard M, Reagan M K, Pearce J A, (2019) Radiogenic isotopes document the start of subduction in the Western Pacific. Earth and Planetary Science Letters, $518: 197-210$.

14. Manatschal, G, Müntener O (2009) A Type sequence across an ancient magma-poor oceanic-continent transition: the example of the western Alpine Tethys ophiolite. Tectonophysics 473(1-2):4-19

15. Manzotti P, Ballèvre $M$, Zucali $M$, Robyr M, Engi M, (2014) The tectonometamorphic evolution of the Sesia-Dent Blanche nappes (internal Western Alps): review and synthesis. Swiss Journal of Geoscience 107:309336

16. McCarthy A, Chelle-Michou C, Müntener O, Arculus R, Blundy J (2018) Subduction initiation without magmatism: the case of the missing Alpine magmatic arc. Geology 46:1059-1062 
17. McCarthy A, Tugend J, Mohn G, Candioti L, Chelle-Michou C, Arculus R, Schmalholz S M, Müntener 0, (2020) A case of Ampferer-type subduction and consequences for the Alps and the Pyrenees. American Journal of Science $320: 313-372$

18. Mohn G, Manatschal G, Müntener O, Beltrando M, Masini E, (2010) Unravelling the interaction between tectonic and sedimentary processes during lithospheric thinning in the Alpine Tethys margins. International Journal of Earth Sciences 99:75-101

19. Mohn G, Manatschal G, Masini E, Müntener O, (2011) Rift-related inheritance in orogens: a case study from the Austroalpine nappes in Central Alps (SESwitzerland and N-Italy). International Journal of Earth Sciences 100:937961

20. Müntener O, Ulmer P, Blundy J, (2021) Superhydrous arc magmas in the Alpine context. Elements , 17:35-40

21. Paterson S C, Ducea M N, (2015) Arc magmatic tempos: gathering the evidence. Elements Magazine, 11:91-98

22. Picazo, S., Ewing, T., Müntener, O., (2019) Paleocene metamorphism along the Pennine-Austroalpine suture constrained by $\mathrm{U}-\mathrm{Pb}$ dating of titanite and rutile (Malenco, Alps). Swiss Journal of Geosciences, 112:517-542

23. Rampone, E., Sanfilippo, A., (2021), The heterogeneous Tethyan oceanic lithosphere of the Alpine ophiolites, Elements Magazine, this volume 
24. Rosenbaum G, Lister G, (2005) The Western Alps from the Jurassic to Oligocoene: spatio-temporal constraints and evolutionary reconstructions. Earth-Science Reviews, 69:281-306

25. Skora S, Lapen, T J, Baumgartner L P, Johnson C M, Hellebrand E, Mahlen N J, (2009) The duration of prograde garnet crystallization in the UHP eclogites at Lago di Cignaga, Italy, Earth and Planetary Science Letters, 287:402-411.

26. Stern R J, Reagan M, Ishizuka O, Ohara Y, Whattam S (2012) To understand subduction initiation, study forearc crust: to understand forearc crust, study ophiolites. Lithosphere, 4(6):469-483

27. Trümpy R (1975) Penninic-Austroalpine boundary in the Swiss Alps: A Presumed former continental margin and its problems. American Journal of Science, 275(A):209-238

28. Tugend J, Manatschal G, Kusznir N.J., Masini E, Mohn G, Thinon I (2014) Formation and deformation of hyperextended rift systems: Insights from rift domain mapping in the Bay of Biscay-Pyrenees. Tectonics, 33(7):1239-1276

29. Tugend, J., Manatschal, G., \& Kusznir, N. J. (2015). Spatial and temporal evolution of hyperextended rift systems: Implication for the nature, kinematics, and timing of the Iberian-European plate boundary. Geology, 43(1), $15-18$

30.Zanchetta S, Garzanti E, Doglioni C, Zanchi A (2012) The Alps in the Cretaceous: a double vergent pre-collisional orogen. Terra Nova, 24:351-356 